\title{
Relationship Analysis Between Leaf-Stomata Characteristics with Cocoa Resistance to Vascular-Streak Dieback
}

\author{
Agung Wahyu Susilo ${ }^{1 *}$, Poppy Arisandy ${ }^{2)}$, Indah Anita-Sari ${ }^{1)}$ and Rudi Harimurti ${ }^{2}$ \\ ${ }^{1}$ Indonesian Coffee and Cocoa Research Institute, J1. PB. Sudirman 90, Jember Indonesia \\ ${ }^{2)}$ Agriculture Faculty, Gadjah Mada University, Yogyakarta \\ ${ }^{*}$ Corresponding author: soesiloiccri@yahoo.com \\ Received: 15 January 2016 / accepted: 19 February 2016
}

\begin{abstract}
Characteristics of leaf-stomata indicate having relationship with the resistance of cocoa to vascular-streak dieback (VSD) caused by Ceratobasidum theobromae. This research has objective to identify the relationship between leaf-stomata characteristics to VSD resistance in order to develop criteria for selection. Trial was establised in randomized-complete block design with three blocks as replications in Kaliwining Experimental Station of Indonesian Coffee and Cocoa Research Institute (ICCRI) using 15 clones which had different background on VSD resistance. Leaf-stomata of the tested clones were characterized using variables of number of stomata, stomata size, width of opened-stomata and size of stomata mouth in three different level of leaf growth, namely flush, young and mature. VSD resistance was assessed by scoring the damage in the scale of 0-6 that the tested clones were classified into five groups of resistance. Analysis of variance indicated a significant effect of cocoa clone to the number of stomata in all categories of leaf sample but the other leaf-stomata characteristics were significantly affected by cocoa clone just at the young and mature leaf. Correlation analysis performed a significant inter-correlation between variables of leaf-stomata characteristics in young leaf and the score of VSD resistance. However, number of stomata and width of opened-stomata in the mature leaf were significantly correlated to the score of VSD resistance. Genetic variance analysis showed a high category of broad sense heritability for the number of stomata and width of the openedstomata in young leaf that both of the variables can be developed as criteria for selection on VSD resistance.
\end{abstract}

Keywords: leaf stomata, Theobroma cacao L., vascular streak dieback, resistance

\section{INTRODUCTION}

Vascular-streak dieback (VSD) which is caused by fungus of Ceratobasidium theobromae (Samuels et al., 2012) is an important disease of cocoa in Indonesia. C. theobromae attacks the cacao plant by infecting leaves, young leaves, or flush and then spread into the xylem tissues. Therefore, the tissues will be damaged and the transportation system of nutrients in the plant will be disrupted. VSD symptoms appear in form of damages in vegetative parts of plant, especially branches and leaves which can be visually seen with symptoms as leaf necrosis and partly yellowish leaf similar with the symptoms of nutrient deficiency. Effective method to control VSD is by replacing susceptible with resistant clones, which have been recommended as resistant planting materials, either in form of clones or hybrids as components of integrated VSD control 
in Indonesia (Susilo et al., 2012). Efforts on developing cocoa planting materials which are resistant to VSD is still constrained by the unavailability of the selection criteria for early detection of resistant genotypes, therefore the evaluation of VSD resistance is still relying on natural VSD infestation in the field. Currently, VSD resistance evaluation is conducted by scoring the plant damage gradation based on the symptom damage in the field (Susilo et al., 2001). This selection process requires a relatively long time because the evaluation process of VSD resistance needs to be done for several times observation to ensure that the response of plant resistance is stable or not biased by environmental effects. Thus, the availability of selection criteria for VSD resistance is required in order to accelerate the selection process that the selection can be done accurately and is not affected by the dynamics of VSD infestation process in the field.

VSD resistance is thought to occur through a complex mechanism involving multiple organ structures of plant, especially in the leaves or young leaves which is caused by $C$. theobromae infections (Guest $\&$ Keane, 2007). Susilo et al. (2014) reported correlation between the level of VSD resistance with branch rejuvenation ability thus it can be presumed that tolerant mechanism would play a role in VSD resistance. Structural resistance mechanisms may also play a role in VSD resistance because the cuticular layer and the epidermal layer of leaf of resistant clones is thicker than the susceptible clones (Prawoto et al., 2013). C. theobromae fungal spores penetrate the epidermis of young leaves that contain water droplets to facilitate basidiospores to germinate before penetrate xylem tissue (Rosmana, 2005). Anita-Sari \& Susilo (2013) reported that there were leaf stomata characteristic differences between resistant clones (PA 191) and susceptible clones
(GC 7 and BL 703) in which the number and diameter of stomata clone PA 191 is smaller than clone GC 29 and BL 703. It could be concluded that the anatomical characteristics of cocoa leaf play a role in VSD resistance. Nevertheless, it is hyphothesized that leaf stomata characteristics play a role in VSD resistance because the spore enter plant through stomata. Banerjee et al. (2014) reported that resistance of mulberry (Morus spp.) against bacterial leaf spot (BLS, Xanthomonas campestris pv. Mori) was related to leaf stomata frequency level. The report mentioned that the leaf stomata frequency of susceptible plants was higher than resistant plants. Earlier, it was also reported that number of stomata and trichome was used as an indicator of the resilience of the vines against downy mildew (Baswarsiati, 1997). Therefore, it is necessary to study the relationship of leaf stomata characteristics with VSD resistance to determine whether the differences in the leaf stomata characteristics are also associated with VSD resistance so that it can be used as criteria for selection and study the mechanisms of VSD resistance.

The relationship between leaf stomata characteristics with VSD resistance based on broad genetic materials has never been reported before. This study aims to determine the relationship between leaf stomata characteristics of cocoa with VSD resistance using larger number of genetic materials which having different background on VSD resistance. Therefore, genetic diversity of leaf stomata characteristics can be understood and used as the basis for determining the criteria of selection. Through this research, how large the proportion of genetic factors of leaf stomata characteristics and the environmental factors can be predicted to have influence. AnitaSari \& Susilo (2014) reported differences in the characteristics of leaf stomata at different altitude of cocoa growing. Anita-Sari \& Susilo 
$(2013,2014)$ used very limited number of genetic materials (only three cacao clones), therefore further research based on broad sense of genetic materials is needed to figure out genetic diversity of leaf stomata characteristics. This paper reports study results as information that can be used in the development of criteria selection for VSD resistance and study the mechanism of VSD resistance.

\section{MATERIALS AND METHODS}

This study used a working collection of cocoa germplasm (Theobroma cocoa $\mathrm{L}$.) grown in Kaliwining Experimental Station of Indonesian Coffee and Cocoa Research Institute (ICCRI) in Jember, East Java, in the altitude of $45 \mathrm{~m}$ asl. with type D of climate according to Schmidt and Ferguson classification. The genetic materials were 15 cocoa clones selected based on the differences of response to VSD resistance which represent the resistant, moderate and susceptible groups. In this field experiment, the clonal planting materials were arranged in a randomized block design with three blocks as replications, and each plot was planted with five plants propagated by top grafting technique. The clonal seedlings were planted in 2007 with spacing distance of $3 \mathrm{~m} \times 3 \mathrm{~m}$, and the plants were already seven years old when the observation was conducted.

Evaluation of VSD resistance was conducted by scoring gradition of plant damage in the field on a scale of $0-6$, according to Susilo \& Anita-Sari (2011) at the peak of dry season in 2014 (August 2014). Plant response the VSD resistance was classified based on the mean value of the scores with the category resistant $(0-<2)$, moderate resistant $(2<$ score $<3)$, moderate susceptible $(3<$ score $<4)$, susceptible $(4<$ score $<5)$, and highly susceptible $(>5)$.

Analysis of the leaf stomata characteristics was carried out in the Laboratory of Genetics, Faculty of Agriculture, Gadjah Mada University, Yogyakarta. Leaf samples were taken from the tested clones at three categories of leaf developmental phases namely flush, young leaves and old leaves. In the phase of flush, the leaves were less than 3 weeks old and the chlorophyll was not yet formed as can be seen from the bright red or yellowish color of the leaves which

Table 1. The list of cocoa clones used for the trial in Kaliwining Experimental Station

\begin{tabular}{ll}
\hline Clones & Ancestry \\
\hline KEE 2 & Introduced from CCI PNG \\
KW 718 & Putative PBC 123 clone from Malaysia \\
KW 617 & Pxplored at Kaliwining Exp. Station, East Java \\
KW 606 & Explored from Blitar District, East Java \\
KW 619 & Explored from Adolina Estate of PTPN IV North Sumatra \\
KW 641 & Progeny of KW 163 x KEE 2 selected in Kalitelepak Estate of PTPN XII, East Java \\
KW 255 & Explored from Jatirono Estate of PTPN XII, East Java \\
KW 468 & EQ X 3360-3 clone introduced from Reading University \\
KW 651 & Progeny of TSH 858 x ICS 13 selected in Kalitelepak Esate of PTPN XII, East Java \\
MCC 01 & A released local clone from North Luwu, South Sulawesi \\
Sulawesi 3 & A released clone resistance to CPB \\
ICCRI 07 & A released clone resistance to CPB \\
KW 635 & Progeny of TSH 858 x Sulawesi 1 selected in Kendeng Lembu Esate of PTPN XII, East Java \\
KW 516 & Explored from Pabatu Estate of PTPN IV, North Sumatra \\
\hline
\end{tabular}


depending on clone types. Young leaves were the phase in which the leaf size had not yet reached a maximum size of about 3-6 weeks old and began to form a new chlorophyll. Old leaves phase occured after the leaves were over 6 weeks old and the chlorophyll had been fully formed. Leaf samples for stomata analysis should be classified because the characteristics of stomata can be affected by the leaf development and $C$. theobromae fungi infections commonly occur in the flush.

Three classifications of the leaves samples were taken from the field. Three leaves per category were taken and used for floral fungal growth. The middle underside of the leaf was smeared with transparent nail polish and then left for 15 minutes to dry and covered with transparent cellotape which was exfoliated to obtain foliar fungi. Each leaf was made into three leaf molds and placed on a glass slide for microscopic observation. Stomata was observed under a microscope with a magnification of 40 times and then photographed using Optilab Pro X-64. Stomata characteristic observation was based on number of stomata, width of stomata opened-mouth, size of stomata mouth, size of stomata conducted using Image Raster. Observation on number of stomata, width of the stomata opened-mouth, size of stomata mouth, size of stomata of leaf samples-clone material experiments were performed one time on each leaf sample in flush, young and old phases.

Data of leaf stomata characteristics was analyzed using ANOVA (Fisher's exact test) with SAS (Statistical Analysis System) 9.1.3 program. The expected mean squared (EMS) of the variance component was used for calculating the value of broad sense heritability as formulated by Mangoendidjojo (2003):

$$
\mathrm{H}=\frac{\sigma_{G}^{2}}{\sigma_{P}^{2}}=\frac{\sigma_{G}^{2}}{\sigma_{P}^{2}+\sigma_{E}^{2}}
$$

The variant phenotypes, genotypes, and error were calculated based on the value of EMS the clonal effect and error of leaf stomata characteristics as the outcome of variance analysis equality (Table 2 ).

Phenotype variance $\left(\sigma_{\mathrm{p}}^{2}\right)$ and genotype variance $\left(\sigma_{\mathrm{G}}^{2}\right)$ were calculated by the following formula:

$\sigma_{G}^{2}=\left(\mathrm{M}_{2}-\mathrm{M}_{3}\right) / \mathrm{r} ; \sigma_{E}^{2}=\mathrm{M}_{3 ;} \sigma_{P}^{2}=\sigma_{G}^{2}+\sigma_{E}^{2}$.

The broad sense heritability was classified into three categories, namely low $(20 \%)$, moderate $(>20 \%-50 \%)$, and high (>50\%) (Mangoendidjojo, 2003).

Relationship between variable of stomata characteristics and VSD resistance was calculated using analysis of covariance following the model of Sigh \& Chaudhary (1979) at 95\% level of confidence using SAS software 9.1.3.

Table 2. Equation of the analysis of variance for the stomata characteristics of cocoa flush which be differentiated based the factors of block and clone

\begin{tabular}{|c|c|c|c|c|}
\hline Sources of variation & Degree of freedom & Mean square (MS) & F-calculated & $\begin{array}{c}\text { Expected mean square } \\
\text { (EMS) }\end{array}$ \\
\hline Block & $\mathrm{r}-1$ & $\mathrm{M}_{1}$ & $\mathrm{M}_{1} / \mathrm{M}_{3}$ & \\
\hline Clone & $g-1$ & $\mathrm{M}_{2}$ & $\mathrm{M}_{2} / \mathrm{M}_{3}$ & $\sigma_{E}^{2}+\mathrm{r}\left(\sigma_{G}^{2}\right)$ \\
\hline Error & $(\mathrm{r}-1)(\mathrm{g}-1)$ & $\mathrm{M}_{3}$ & - & $\sigma_{E}^{2}$ \\
\hline Total & $\mathrm{rg}-1$ & & & \\
\hline
\end{tabular}




$$
\begin{array}{ll}
\mathrm{r}_{A B}= & \frac{\operatorname{Cov}(A, B)}{\sqrt{\left(\sigma_{A}^{2}\right)\left(\sigma_{B}^{2}\right)}} \\
\operatorname{Cov}(A, B) & =\text { variance of phenotypic/genotypic trait A to B } \\
\mathrm{r}_{A B} & =\begin{array}{l}
\text { correlation of phenotypic/genotypic trait A with } \\
\text { trait B }
\end{array} \\
\sigma^{2} A & =\text { variance of phenotypic/genotypic trait A } \\
\sigma^{2} B & =\text { variance of phenotypic/genotypic trait B }
\end{array}
$$

The analysis was conducted based on VSD disease resistance score using hierarchical clustering method. The use of this clustering method is intended to obtain VSD resistance interpretations, namely resistance, moderate resistance, moderate susceptible and susceptible. Before the analysis, data were standardized by dividing the value of variable with standard deviation based on the average of linkage method. Cluster analysis was performed using SAS 9.1.3 software.

\section{RESULTS AND DISCUSSION}

\section{VSD Resistance Variation}

The results of VSD resistance evaluation showed significant differences in VSD resistance response between clones with variations of the mean score of crop damage ranges from 1.0 to 5.0 (Table 3). Based on the VSD resistance evaluation, a score of 0 or free from VSD attack was not found, similar to the previous report (Susilo \& AnitaSari, 2011) which showed that there was no immune symptom found on VSD resistance. Based on the results of cluster analysis, it was known that the resistances of tested clones were divided into 5 groups performing variation of VSD resistance (Figure 1). The closer of the distance, the higher degree of VSD resistance similarity. On the other hand, the farther distance, the higher the difference

Table 3. Mean score of VSD symptoms on some cocoa clones established at Kaliwining Experimental Station of VSD endemic area

\begin{tabular}{lcc}
\hline Cocoa clones & Mean of score ${ }^{*}$ & Interpretation of VSD resistance \\
\hline KEE 2 & $1.00 \mathrm{~h}$ & Resistant \\
Sulawesi 1 & $2.00 \mathrm{~g}$ & Resistant \\
KW 718 & $2.00 \mathrm{~g}$ & Resistant \\
KW 617 & $2.33 \mathrm{~g}$ & Moderate resistant \\
KW 606 & $2.66 \mathrm{ef}$ & Moderate resistant \\
KW 619 & $3.00 \mathrm{de}$ & Moderate resistant \\
KW 641 & $3.00 \mathrm{de}$ & Moderate resistant \\
KW 255 & $3.00 \mathrm{de}$ & Moderate resistant \\
KW 468 & $3.33 \mathrm{~cd}$ & Moderate resistant \\
KW 651 & $3.33 \mathrm{~cd}$ & Moderate resistant \\
MCC 01 & $3.67 \mathrm{bc}$ & Moderate resistant \\
Sulawesi 3 & $3.66 \mathrm{bc}$ & Moderate resistant \\
ICCRI 07 & $3.66 \mathrm{bc}$ & Moderate resistant \\
KW 635 & $3.89 \mathrm{~b}$ & Moderate resistant
\end{tabular}

Note: *) Values in the same column followed by the same letter are not significantly different according to Duncan Multiple Range Test (DMRT) at $95 \%$ of significant level. 
of VSD resistance. It can be seen that the resistant clones of KEE 2 and Sulawesi 1 indicated close distance between each other. In the previous report, the results of VSD resistance evaluation against cocoa germplasm collections in Kaliwining Experimental Station were grouped into four groups namely resistant, moderate resistant, moderate susceptible and susceptible (Puslitkoka, 2011). After a period of observation, there was an increase in the VSD resistance intensity, thus VSD resistance variation was getting wider.

Based on Figure 1, the tested clones can be grouped into five groups of VSD resistance. Group I consisted of KEE 2 (mean score 1.0), Group II consisted of Sulawesi 1, KW 718 and KW 617 (mean score of 1.0 to 2.33), Group III consisted of KW 606, KW 619, KW 641 and KW 255 (mean score of 2.66 to 3.0), Group IV consisted of KW 468, KW 651, MCC 01, Sulawesi 3, ICCRI 07, KW 635 (mean score of 3.33 to 3.89), and Group V consisted of KW 516 (mean score 5.0). The results of this study indicated that KEE 2, which has the highest level of VSD resistance as shown by the lowest score, followed by Sulawesi 1 suggested as VSD resistant clone. In addition, there are several other clones belong to the same group with Sulawesi 1, namely KW 718 and KW 617 categorized as VSD resistant. KW 516 showed the highest mean score (5.0), thus it is classified as susceptible to VSD though the value of the score did not reach the highest score of VSD attack (6.0) which was classified as highly susceptible (Susilo \& Anita-Sari, 2011). The result of this grouping is in line with previous VSD resistance classifications that had been applied to crop damage score $<2.0$ (KEE 2, Sulawesi 1, KW 718 and KW 617) which was categorized as resistant, scores

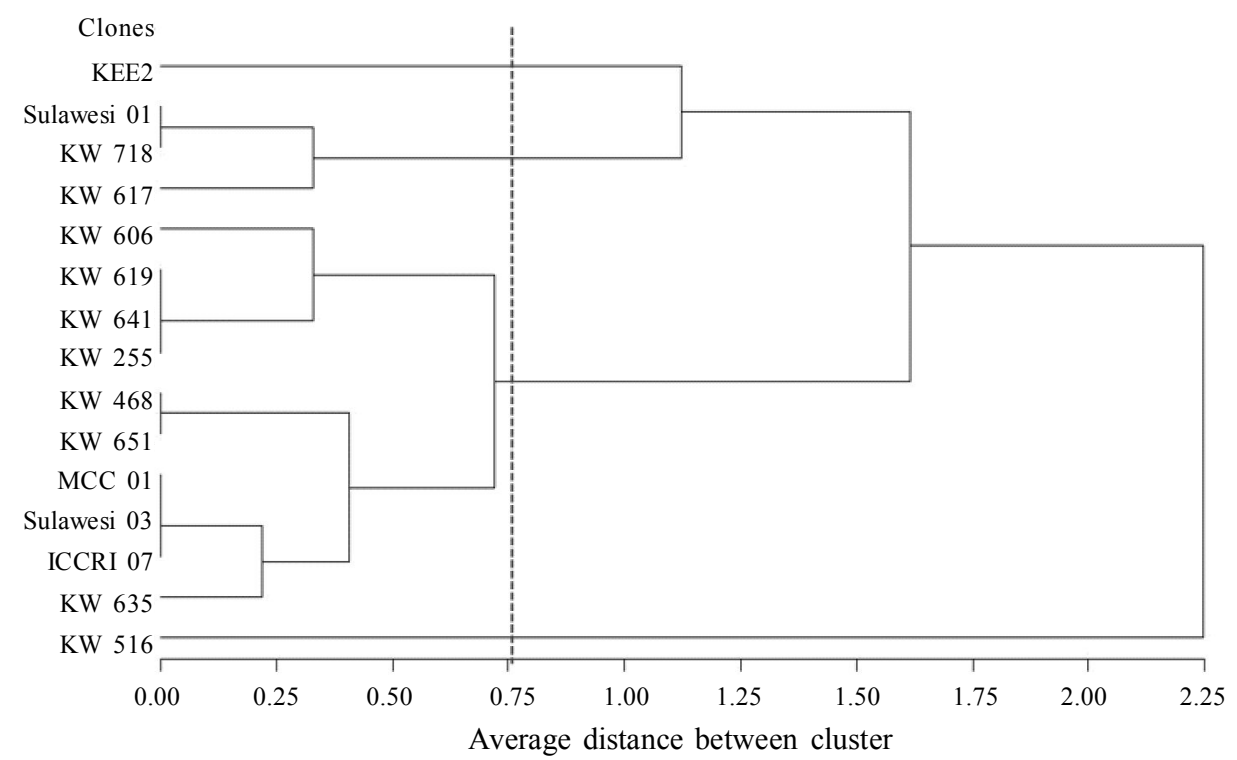

Figure 1. Clustering the tested clones according to the score of plant damage due to VSD field-infestation at the Kaliwining Experimental Station of ICCRI 
of damage 2.0-<3.0 (KW 606, KW 619, KW 641, KW 255) which was categorized as moderate resistant, for damage scores 3.0- $<4.0$ (KW 468, KW 651, MCC 01, Sulawesi 03, ICCRI 07 and KW 635) included as somewhat susceptible, for damage score of 4.0-<5.0 (KW 516) included as susceptible, and damage score $>5.0$ to 6.0 included as highly susceptible category. Results of this study showed that clones with very susceptible category was not found because generally the cocoa plants were grown under VSD endemic conditions and will be heavily damaged or even die so that the plants may not grow well. It is reported that the death rate of VSD susceptible cocoa in the field could reach $>50 \%$ (Keane, 2000 ; Susilo \& Anita-Sari, 2011).

\section{Leaf-stomata characteristics}

The results of variance analysis of stomata characteristics on three kinds of leaf-development phases (flush, young leaves and old leaves) showed significant influence of clones against number of stomata. Mean while the effect of clone on stomata size, width of stomata opened-mouth and size of stomata mouth could apparently be seen only in the young leaves and old leaves while the influence of the clones was not significant to these variables on the flush (Table 4). The mean of width of the stomata opened-mouth and size of stomata mouth in flush was narrower than in young leaves and old leaves because the flush development has not yet reached the maximum size which can influence the development of leaf-stomata. Stomata is part of the leaf epidermis network, thus the progress would also depend on the developmental phase of the leaves. Young leaves is an optimal representation of the development phase so that the development of stomata is alleged to have reached a maximum size, whereas the old leaf samples can only change the size and shape of the leaf stomata because some networks may exist and begin to malfunction. The results of this study showed that the average of width of stomata openedmouth, stomata size, and stomata mouth size of old leaves was greater than those of flush and tend to be narrowed when compared to young leaves. In this case, the stomata activity is strongly influenced by environmental conditions, particularly humidity, light, $\mathrm{CO}_{2}$ levels and the circadian clock (Melotto et al., 2008).

Leaf developments in flush as well as in young leaf phase are very important in enduring VSD because $O$. theobromae infection into plant tissue occurs through the leaves in flush or young leaves phase (Keane, 2000). C. theobromae spores penetrate through the layers of the epidermis of young leaves that contain water droplets where basidiospora is easily to germinate and get into the xylem tissue (Rosmana, 2005). Thus, the stomata variance characteristics on the leaf development phase can reflect the characteristics of VSD resistance traits. The plant resistance mechanism to pathogens involves complex mechanisms such as the formation of antifungal compounds, defense proteins, enzyme chitinase, lignification or hypersensitivity reaction (Stewart \& Globig, 2011). Plants structural changes can be linked to the changes in the biochemical processes of plants so that certain chemical compounds can form a structural resilience that would inhibit development of pathogens. Lignification is one of the result of biochemical reaction to structural resistance in response to infection of fungi, bacteria, viruses and nematodes (Miedes et al., 2014). Melotto et al. (2006) reported that the stomata was part of plant resistance system to bacterial infections, while lignification of stomata-closing cells of the leaves indicated to play a role in Coffea arabica plant resistance to Hemileia vastatrix (Sumardiyono, 2000; do Céu Silva et al., 2006) and the resistance of wheat Triticum 
aestivum against the fungi which cause leaf rust (Puccinia recondita $f$. sp. tritici) (Southerton \& Deverall, 1990). Therefore, discussion of the results of the research will be focused on the different characteristics of stomata on flush and young leaves which are associated with VSD resistance.

The results of the correlation analysis between leaf stomata characteristics with VSD resistance showed that there were differences in the third leaf sample (Table 5). In flush phase, there was no significant correlation between leaf stomata characteristics with VSD resistance. At young leaf phase, all stomata characteristics were significantly positive correlated to score of VSD resistance. In old leaf phase, only the number of stomata and stomata size were significantly positive correlated to score of VSD resistance. In flush phase, it was known that

Table 4. Mean square of stomata characteristics on different phases of leaf growth on cocoa clones having different background on VSD resistance

\begin{tabular}{|c|c|c|c|c|c|}
\hline Leaf growth phase & Source of variation & Number of stomata & Stomata size & $\begin{array}{c}\text { Width of } \\
\text { opened-stomata } \\
\text { mouth }\end{array}$ & Stomata mouth size \\
\hline \multirow[t]{3}{*}{ Flush } & Clone & $471.43 *$ & 105,333 ns & 0.29 ns & 294.480 ns \\
\hline & Error & 63.10 & 9,093 & 0.25 & 243.193 \\
\hline & Total & 669.55 & 42,559 & 0.62 & 318.710 \\
\hline \multirow[t]{3}{*}{ Young leaf } & Clone & $94.98 *$ & $3,313 *$ & $0.54 *$ & $494.270 *$ \\
\hline & Error & 12.91 & 1,574 & 0.08 & 167.240 \\
\hline & Total & 97.05 & 8,696 & 1.07 & 608.010 \\
\hline \multirow[t]{3}{*}{ Mature leaf } & Clone & $171.91 *$ & $4,665 *$ & $0.37 *$ & $230.310 *$ \\
\hline & Error & 71.68 & 1,830 & 0.07 & 81.920 \\
\hline & Total & 510.11 & 23,280 & 1.81 & 1478.060 \\
\hline
\end{tabular}

Notes: ${ }^{*}$ Significantly different and ${ }^{\text {ns) }}$ not significantly different according to Fisher test at $\alpha=5 \%$.

Table 5. Coefficient of correlation between the characteristics of leaf stomata with the score of VSD symptom

\begin{tabular}{|c|c|c|c|c|c|c|}
\hline $\begin{array}{l}\text { Leaf growth } \\
\text { phase }\end{array}$ & Stomata characteristics & VSD score & $\begin{array}{l}\text { Number of } \\
\text { stomata }\end{array}$ & $\begin{array}{l}\text { Stomata } \\
\text { mouth size }\end{array}$ & $\begin{array}{c}\text { Width of } \\
\text { opened } \\
\text { stomata mouth }\end{array}$ & Stomata size \\
\hline \multirow[t]{5}{*}{ Flush } & VSD score & 1 & & & & \\
\hline & Number of stomata & $0.510^{\mathrm{ns}}$ & 1 & & & \\
\hline & Stomata mouth size & $-0.323^{\mathrm{ns}}$ & $0.093^{\text {ns }}$ & 1 & & \\
\hline & Opened stomata width & $-0.378^{\mathrm{ns}}$ & $-0.280^{\mathrm{ns}}$ & $0.535 *$ & 1 & \\
\hline & Stomata size & $-0.433^{\mathrm{ns}}$ & $-0.176^{\mathrm{ns}}$ & $0.784 *$ & $0.874 *$ & 1 \\
\hline \multirow[t]{5}{*}{ Young leaf } & VSD score & 1 & & & & \\
\hline & Number of stomata & $0.704 *$ & 1 & & & \\
\hline & Stomata mouth size & $0.702 *$ & $0.764 *$ & 1 & & \\
\hline & Opened stomata width & $0.673 *$ & $0.757 *$ & $0.816 *$ & 1 & \\
\hline & Stomata size & $0.790 *$ & $0.732 *$ & $0.650 *$ & $0.621 *$ & 1 \\
\hline \multirow[t]{5}{*}{ Mature leaf } & VSD score & 1 & & & & \\
\hline & Number of stomata & $0.670 *$ & 1 & & & \\
\hline & Stomata mouth size & $0.569 *$ & $0.484^{\text {ns }}$ & 1 & & \\
\hline & Opened stomata width & $0.083^{\text {ns }}$ & $-0.036^{\text {ns }}$ & $0.516 *$ & 1 & \\
\hline & Stomata size & $0.295 \mathrm{~ns}$ & $-0.006^{\mathrm{ns}}$ & $0.531 *$ & $0.725 *$ & 1 \\
\hline
\end{tabular}


developmental phase of stomata has not reached maximum size. Therefore, the variance cannot be distinguished significantly between clones through this observation although the precursor possibilities can only be detected through more accurate observation methods. The results of this study indicated that the leaf developmental phase has significant effect on the leaf stomata characteristics associated with VSD resistance. Young leaves phase appears to be optimal for the development of leaf stomata characteristics which is associated with VSD resistance.

In the young leaf phase, all leaf stomata characteristics were positively correlated each other. The larger of leaf stomata size, the greater chance of $C$. theobromae spores to infect plant tissues as shown by positive correlation between leaf stomatal characteristic with VSD damage scores. Determination of leaf stomata characteristics on VSD resistance selection criteria should consider the value of genetic para meters that only broadsense heritability in the higher category can easily passed on derivatives will be selected as the selection criteria. The results of the analysis on genetic diversity of stomata characteristics in young leaf samples indicated that number of stomata and width of stomata opened-mouth showed high heritability while width of stomata mouth and stomata size showed moderate heritability (Table 6). Susilo \& Anita-Sari (2011) reported that VSD resistance evaluation on hybrid cacao based on the scores of crop damage has high broad-sense heritability (0.93), thus it can be concluded that the assessment of VSD resistance by a score of damage will be effective in describing the level of VSD resistance. Data indicated that only the resistant genotypes were able to survive in the conditions where VSD attacks in high intensity. Hence, the apparent positive correlation between number and width of stomata with VSD damage score reflects the relationship between the leaf stomata characteristics with VSD resistance as a result the leaf stomata characteristics can be developed as VSD resistance selection criteria.

\section{Clone performance}

Grouping the experimental material clones based on the characteristics of stomata on young leaf sample provides results which were similar the results of grouping based on VSD denage scores (Figure 2). The result of this grouping put VSD resistant clones, namely KEE 2, Sulawesi 1 and KW 718 located at distances close to each other but apart with KW 516 clones which is susceptible to VSD. In this case, the higher the level of VSD resistance, the lower the aaverage value of the leaf stomata characteristics will be. The results are consistent with report of Susilo \& Anita-Sari (2013) who stated that number and diameter of stomata of PA 191 (VSD resistant) were lower than

Table 6. Genetic parameters of the stomata chacteristics at various leaf growth of cocoa clones having different background of VSD resistance

\begin{tabular}{lccccc}
\hline Stomata characteristics & \multicolumn{1}{c}{$\sigma_{\mathrm{G}}^{2}$} & \multicolumn{1}{c}{$\sigma_{\mathrm{E}}^{2}$} & $\sigma_{\mathrm{P}}^{2}$ & $\begin{array}{c}\text { Broad sense } \\
\text { heritability }(\mathrm{H})\end{array}$ & Interpretation of $\mathrm{H}$ \\
\hline Number of stomata & 27.59 & 12.19 & 39.78 & 69.36 & High \\
Size of stomata mouth & 110.19 & 163.68 & 273.87 & 40.23 & Moderate \\
Width of the opened-stomata mouth & 0.15 & 0.09 & 0.27 & 55.55 & High \\
Stomata size & 579.82 & 1574.30 & 2408.04 & 24.08 & Moderate \\
\hline Note: Heritability $(\mathrm{H})$ is categorized as high $(\mathrm{H}>50 \%)$, medium $(20 \%<\mathrm{H}<50 \%)$ and low $(\mathrm{H}<20 \%)$. &
\end{tabular}


BL 703 and GS 29 (VSD susceptible). Prawoto et al. (2013) reported that VSD resistant clones (Sulawesi 01 and Sca 6) had lower stomata density than VSD susceptible clones (TSH 858 and ICS 60). Visually, the differences in stomata density of young leaves of resistant clone and susceptible clones are shown in Figure 3.

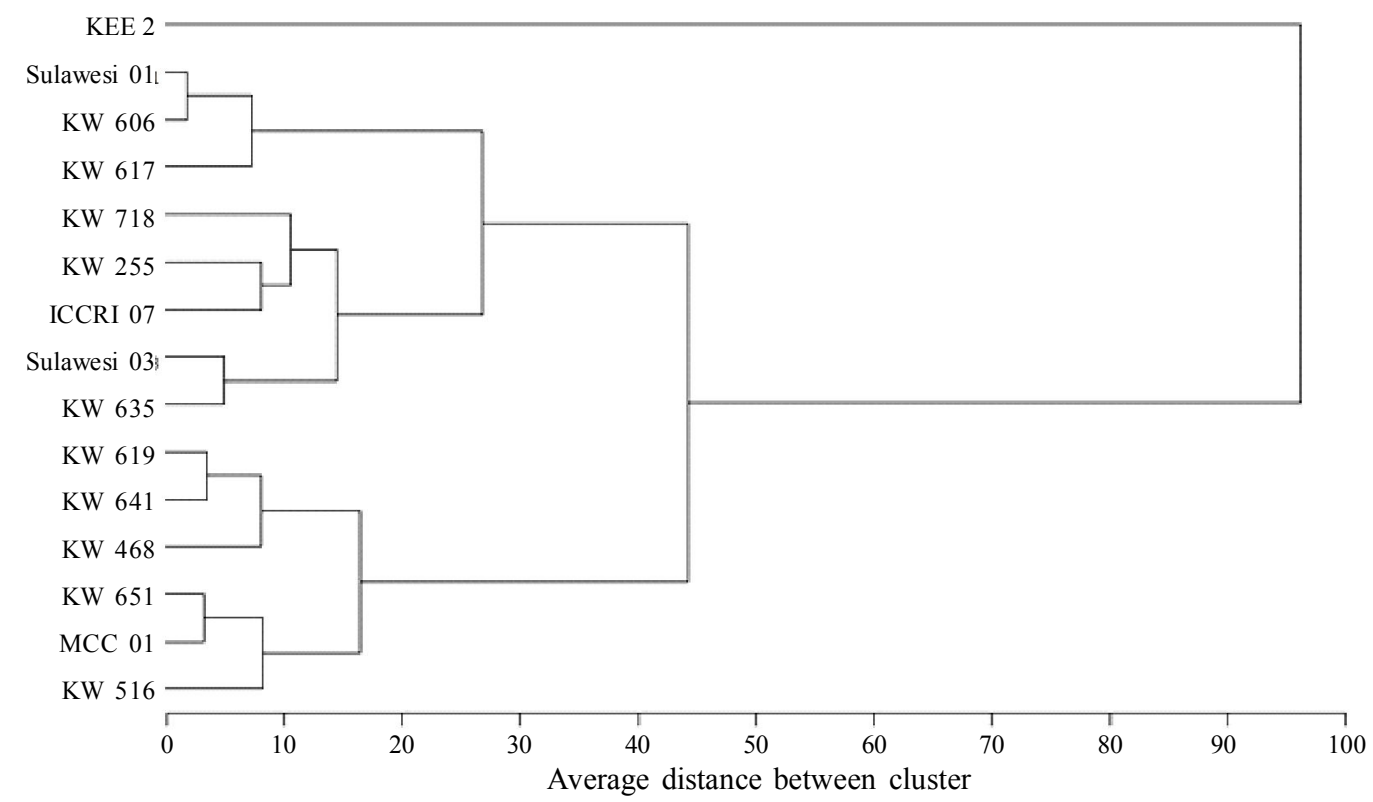

Figure 2. Clustering of the tested clones according to stomata characteristics of young leaf

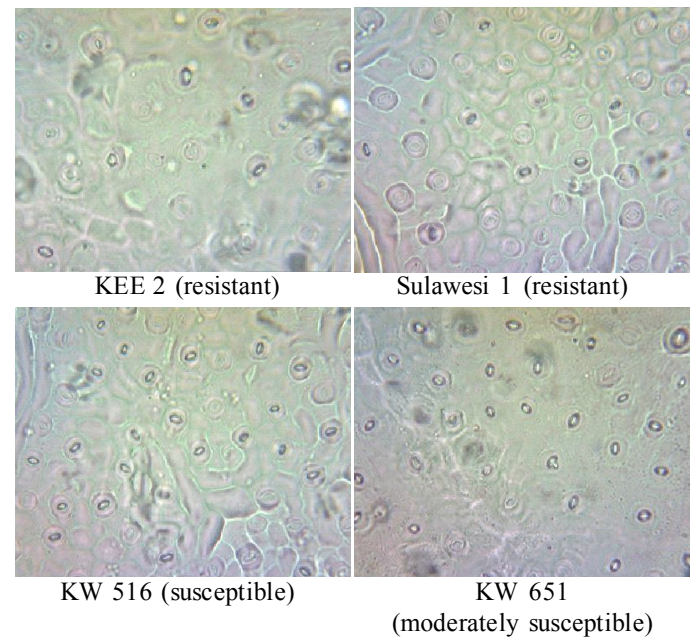

Figure 3. Visual differences of stomata characteristics between the resistant clones of KEE and Sulawesi 1 which performing lower density of stomata compared to the susceptible clones of KW 516 and KW 651 (objects in the cycle are the leaf stomata) 


\section{CONCLUSION}

There is a positive relationship between VSD damage levels in 15 clones of cacao which have different nature of resistance to VSD at young leaf characteristics of stomata (number of stomata, width of stomata mouth, stomata size, and width of stomata opened-mouth). The characteristics of young leaf stomata reflect the nature of VSD resistance. The number of stomata and the width of stomata opened-mouth have high heritability, respectively 69.36 and 55.55 , therefore it can be developed as a selection criteria for VSD resistance traits.

\section{REFFERENCES}

Anita-Sari, I. \& A.W. Susilo (2013). Investigation of different characters of stomata on three cocoa clones with resistance level difference to VSD (vascular streak dieback) disease. Journal of Agriculture Science and Technology, 3, 703-719.

Anita-Sari, I. \& A.W. Susilo (2014). Effect of genetic and altitude differences on stomata characters as resistance indicators to vascular streak-dieback (VSD) in cocoa (Theobroma cacao L.). Journal of Agriculture Science and Technology, B4, 157-163.

Banerjee, R.; S. Chattopadhyay; A.K. Saha \& S.N. Kumar (2014). Association of morphological and biochemical features of mulberry lines with resistance to bacterial leaf spot. Phytopathology and Plant Protection, 47, 2020-2032.

Baswarsiati (1997). Penilaian stomata dan bulu daun sebagai penciri ketahanan beberapa klon tanaman anggur terhadap Plasmopara viticola. Zuriat, 5, 29-35.

Guest, D. \& P. Keane (2007). Vascular-streak dieback: A new encounter disease of cacao in Papua New Guinea and Southeast Asia caused by the obligate Basidiomycete, Oncobasidium theobromae. Phytopathology, 97, 1654-1657.

Keane, P.J. (2000). Biology and control of vascular streak dieback of cocoa. Warta Pusat Penelitian Kopi dan Kakao Indonesia, 17, 46-59.

Mangoendijojo, W. (2003). Dasar-Dasar Pemuliaan Tanaman. Kanisius, Yogyakarta.

Melotto, M; W. Underwood; J. Koczan; K. Nomura \& Sheng Yang He (2006). Plant stomata function in innate immunity against bacterial invasion. Cell, 126, 969-980.

Melotto, M; W. Underwood \& Sheng Yang He (2008). Role of stomata in plant innate immunity and foliar bacterial diseases, Annual Review Phytopathology, 46, 101-122.

Miedes, E.; R. Vanholme; W. Boerjan \& A. Molina (2014). The role of secondary cell wall in plant resistance to pathogens. Plant Science, 5, 78-90.

Prawoto, A.A.; T.I. Santoso; Marifah; L. Hartanto \& Sutikno (2013). Terpene profile, leaf anatomy, and enzyme activity of resistant and susceptible cocoa clones to vascular-streak dieback disease. Pelita Perkebunan, 29, 197-209.

Puslitkoka (2009). Usulan Pelepasan Klon Kakao Tahan Penyakit Pembuluh Kayu (Vascular-streak dieback, VSD), Sca 6 dan DRC 15. Pusat Penelitian Kopi dan Kakao Indonesia, Jember, Indonesia

Rosmana, A. (2005). Vascular-streak dieback (VSD): Penyakit baru pada tanaman kakao di Sulawesi. Prosiding Seminar Ilmiah dan Pertemuan Tahunan PEI dan PFI XVI. Komisi Daerah Sulawesi Selatan.

Samuels, G.J.; A. Ismaiel; A. Rosmana; M. Junaid; D. Guest; P. McMahon; P. Keane; A. Purwantara; S. Lambert; M. RodriguezCarres \& M.A. Cubeta (2012). Vascular streak dieback of cacao in Southeast Asia and Melanesia: in planta detection of the pathogen and a new taxonomy. Fungal Biology, 116, 11-23. 
Singh, R.K. \& B.D. Chaudary (1979). Biometrical Methods in Quantitative Genetic Analysis. Kalyani Publishers. New Delhi.

Stewart, P. \& S. Globig (2011). Phytopathology in Plants. Apple Academic Press.

Sumardiyono, C. (2000). Ketahanan Terimbas Kendala dan Prospeknya dalam Pengendalian Penyakit Tumbuhan. Pidato Pengkukuhan Guru Besar Fakultas Pertanian. Universitas Gadjah Mada. Yogyakarta.

Susilo, A.W.; D. Suhendy \& S. Mawardi (2001). Daya gabung sifat kerentanan terhadap penyakit vascular-streak dieback beberapa klon kakao. Pelita Perkebunan, 17, 97- 104 .
Susilo, A.W. \& I. Anita-Sari (2011). Respons ketahanan beberapa hibrida kakao (Theobroma cacao L.) terhadap serangan penyakit pembuluh kayu (vascular-streak dieback). Pelita Perkebunan, 27, 77-87.

Susilo, A.W.; S. Mawardi \& I. Anita-Sari (2012). Seratus tahun pemuliaan kakao di Indonesia. Prosiding Simposium Kakao 2012.

Susilo, A.W. \& I. Anita-Sari (2014). Hubungan karakteristik pertunasan dengan ketahanan kakao terhadap VSD. Pelita Perkebunan, 30, 191-189.

$$
* * 0 * *
$$

